\title{
УЧЕТ НЕОДНОРОДНОСТЕЙ ВЕРХНЕЙ ЧАСТИ РАЗРЕЗА ПРИ ПЕРЕОБРАБОТКЕ СЕЙСМИЧЕСКИХ ДАННЫХ В НЕДОСТАТОЧНО ИЗУЧЕННЫХ ГЛУБОКИМ БУРЕНИЕМ РАЙОНАХ КРАЙНЕГО СЕВЕРА ЯНАО
}

Касьянов В.В., Таужнянский Д.Г.

\section{( «ТюменНИИгипрогаз», г. Тюмень)}

Переобработка сейсмических данных МОГТ площадных и региональных профилей прошлых лет на современных программных комплексах позволяет получить более качественную информацию о геологическом строении исследуемых территорий. Основньпи процедурами обработки, определяющими качество окончательных данных, являются процедуры, позволяющие устранить влияние скоростньх неоднородностей в ВЧР (верхняя часть разре3а). В докладе кратко рассмотрены основные способы коррекции неоднородного строения толщщи многолетнемерзлых пород (ММП) и приведены некоторые результаты обработки данных 2D MOГT с учетом влияния неоднородного строения ВЧР на площадях недостаточно изученных глубоким бурением.

По результатам вертикального сейсмического профилирования (ВСП), проведенного на многих площадях ЯНАО мощность ММП изменяется от первых десятков до нескольких сотен метров, скорость прохождения продольных волн в промерзших породах составляет $2200-3500 \mathrm{~m} / \mathrm{c}$, в зонах отсутствия ММП изменяется от 400 до $2000 \mathrm{~m} / \mathrm{c}$ и завнсит в основном от литологического состава, степени уплотнения и водонасыщения пород, слагаюших ВЧР. На временных разрезах такие изменения приводят $\mathbf{k}$ образованию ложных структур, не связанных с геологическим строением.

Отыт обработки сейсмических данных в районах крайнего севера ЯНАО показал, что для учета влияний неоднородностей ВЧР необходимо использовать интерпретационный подход, основанный на комплексном анализе всех имеющихся материалов (МОГТ, ВСП, скважинных данных, орогидрографии). Совместное использование всей имеющейся информации позволяет минимизировать ошибки в расчете статических поправок за ВЧР. В качестве основной методики учета влияния неоднородностей ВЧР по сейсмическим данным исполгзовался интерпретақионный подход учета длинопериодных искажкений сейсмических волновых полей, вызванных зоной ММП, предложенный Е.К.Королевым. По существу данный метод заключается в замене верхнего неоднородного слоя более однородной изотропной средой с плавно изменяющимися кинематическими характеристиками. Последовательность процедур расчета статических поправок за неоднородное строение ВЧР представлена в виде блок-схемы на рисунке 1. На рисунке 2 показаны некоторые результаты обработки данных площадных профилей с учетом кинематических неоднородностей в ВЧР на Юбилейном месторождении. Комплексный подход учета ВЧР позволил получить более достоверную информацию о строении осадочной толши изучаемой территорин.

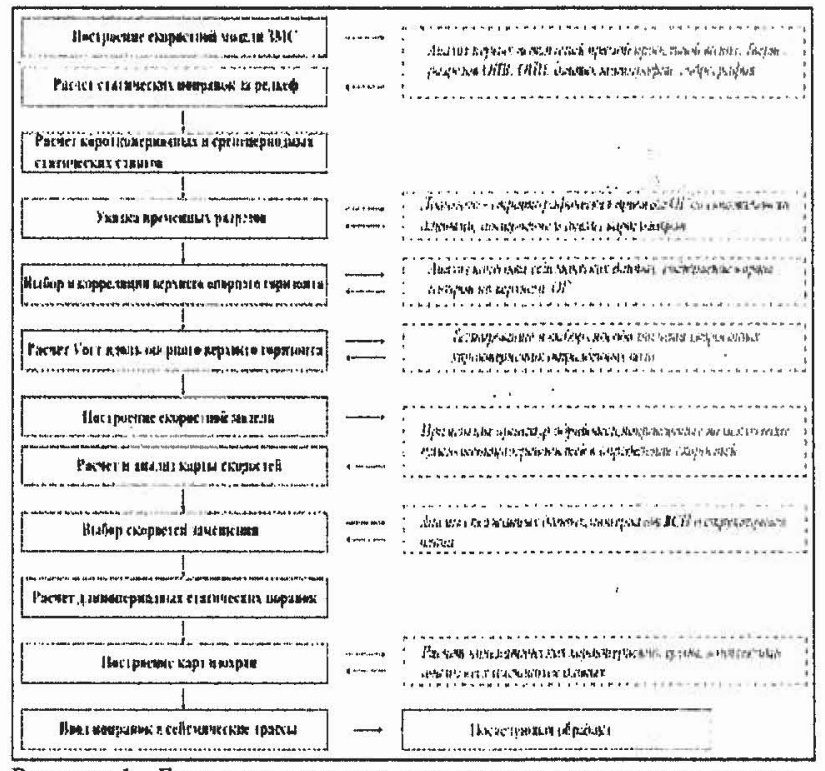

Рисунок 1- Бток-схема расчета статических поправок за неоднородное строение ВЧР
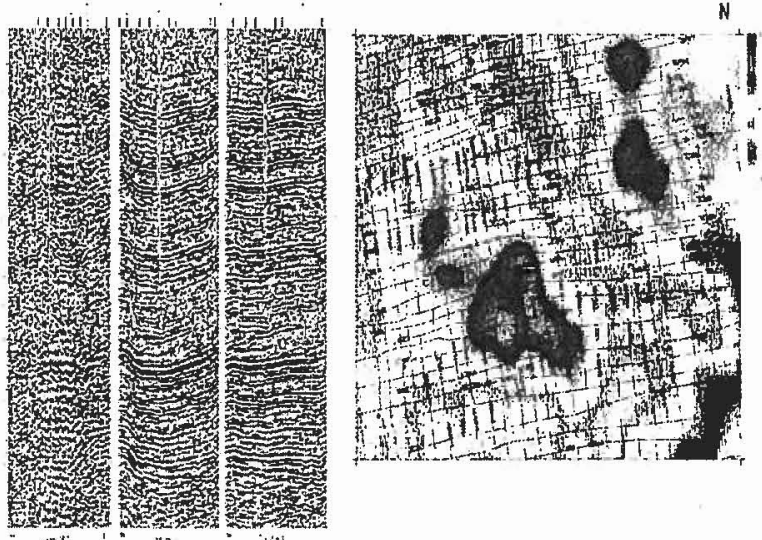

a) 6)"

B)

г)

Рисунок 2 - Сопостав.тение временных разрезов МОГТ по линии профиля 7602003 на различных стадиях учета влияния неоднородностей ВЧР: a) разрез со статическими поправками за рельеф; б) разрез пос.те коррекики короткопернодных и сренепериодныг временных сдвитов; в) разрез после учета втияния дтиннопериодной компоненты статики; r) карта статических поправок за неоднородное строенне ВЧР 